\title{
Treatment Needs for Dental Caries, Restorative Care Index, and Index of Extractions in Adolescents 12 and 15 Years Old
}

CE Medina-Solís ${ }^{1}$, AP Pontigo-Loyola ${ }^{1}, \mathrm{M}_{\text {Mendoza-Rodríguez }}^{1}$, SE Lucas-Rincón ${ }^{1}$, S Márquez-Rodríguez JJ Navarrete-Hernandez ${ }^{1}$, G Maupomé2, 3

\begin{abstract}
Objective: To determine the Treatment Needs Index (TNI) for dental caries, the restorative Care Index (CI), and to introduce a Tooth Extractions Index (TEI) to estimate past and current treatment needs among Mexican adolescents.

Subject and Methods: A descriptive cross-sectional study was carried out on 1538 adolescents aged 12 and 15 years in the state of Hidalgo, Mexico, to collect decayed, missing, filled teeth (DMFT) data to describe TNI, CI and TEI indices.

Results: Higher TNI was identified in younger male teenagers who had always lived in the same community, without dental visits in the last year, and who had poorer socio-economic markers. Higher CI was found in older, female subjects who had moved in their lifetimes to a new community in the area, with dental visits in the last year and who had better socio-economic markers. Higher TEI was found in older, female teenagers who had moved in their lifetimes to a new community in the area, without dental visits in the last year, and who had worse socio-economic markers.

Conclusions: We observed high rates of treatment needs for dental caries and little experience of restorative treatment. While dental extractions due to advanced caries should ideally be zero, relatively few adolescents had this treatment experience. Despite the fact that the overall background of these adolescents is rather homogeneous, it was still possible to find that treatment needs' indices (past and present needs) appeared to be modified by sociodemographic and socio-economic variables.
\end{abstract}

Keywords: Dental caries, oral health, restorative treatment, treatment needs, tooth extractions

\section{Necesidades de Tratamiento para Caries Dental, Indice de Cuidados Restauradores, e Î́ndice de Extracciones en Adolescentes de 12 y 15 Años de Edad}

CE Medina-Solís ${ }^{1}$, AP Pontigo-Loyola ${ }^{1}$, M Mendoza-Rodríguez $^{1}$, SE Lucas-Rincón ${ }^{1}$, S Márquez-Rodríguez ${ }^{1}$, JJ Navarrete-Hernandez ${ }^{1}$, G Maupomé2, 3

\begin{abstract}
RESUMEN
Objetivo: Determinar las necesidades de tratamiento para caries dental (INT), el índice de cuidados restauradores (IC) así como proponer un índice que haga referencia a las extracciones dentales (IE), para estimar necesidades de tratamiento actual y pasada en adolescentes mexicanos.

Material y Métodos: Se realizó un estudio transversal descriptivo en 1538 adolescentes de 12 y 15 años en el Estado de Hidalgo, México. Empleando el índice CPOD se calcularon los índices TNI e IC; asimismo se propone un IE a las que ha estado expuesta la población.

Resultados: El INT fue mayor en los de 12 años, hombres, los que vivieron siempre en la misma comunidad, que no tuvieron visita al dentista en el último año, y con marcado nivel socioeconómico

From: ${ }^{1}$ Área Académica de Odontología del Instituto de Ciencias de la Salud de la Universidad Autónoma del Estado de Hidalgo, Pachuca, Hidalgo, México, ${ }^{2}$ Indiana University/Purdue University at Indianapolis School of

Correspondence: CE Medina Solís, Avenida del Álamo \# 204, Fraccionamiento Paseo de los Solares, Colonia Santiago Tlapacoya, CP. 42110, Pachuca de Soto, Hidalgo, México. E-mail: cemedinas@yahoo.com
\end{abstract} Dentistry, Indianapolis, Indiana, USA and ${ }^{3}$ The Regenstrief Institute, Inc, Indianapolis, Indiana, USA. 
bajo. El IC fue mayor en los sujetos de 15 años, las mujeres, con migración interna, que si tuvieron visita al dentista en el último año, y con mejor nivel socioeconómico. El IE fue mayor en los de 15 años, mujeres, con migración interna, que no tuvieron visita al dentista en el último año, y con peores condiciones socioeconómicas.

Conclusiones: Se observaron altas necesidades insatisfechas de tratamiento para caries dental y poca experiencia de tratamiento restaurador. Las extracciones se observaron en pocos adolescentes, considerando cero como ideal. A pesar de que los antecedentes de estos adolescentes es bastante homogéneo, fue posible encontrar que los índices de necesidades de tratamiento (necesidades presentes y pasadas) parecen ser modificados por variables socio-demográficas y socioeconómicas.

Palabras clave: Salud bucal, caries dental, necesidades de tratamiento, tratamiento restaurador, extracciones dentales

West Indian Med J 2013; 62 (7): 637

\section{INTRODUCTION}

The adolescent population in Mexico grew in the second half of the $20^{\text {th }}$ century from five to 21 million people, with a relative contribution to population growth of about $22 \%$. According to the National Population Council (CONAPO), its growth rate was above 4\% annually in the 1960 s and later decreased gradually. Although teenagers are one of the healthiest population groups as far as general health is concerned, this group uses fewer health services, and has low mortality rates; it also is the age in life when exposure begins for various risk factors for health problems (1). Multiple, rapid changes in physical, psychological and social domains may be associated with specific patterns of disease and unusual presentations of symptoms - compounded by agespecific communication challenges and bursts in developing and affirming individual personality traits (2).

Although the World Health Organization (WHO) proposed a definition of health as a "state of complete physical, mental and social welfare and not just the absence of disease", considerable progress in developing functional health measures has made this definition more dynamic including the overall agreement that oral health is part of overall health (3). Because dental caries (tooth decay) is one of the most common chronic diseases in children and adolescents in Mexico [prevalence is about 70 and $85 \%$, respectively, in the permanent dentition at 12 years of age (3, 4)], it is considered a public health problem. It is also widely acknowledged that in the industrialized world and in emerging economies, the disease is concentrated in population groups affected by social and economic disadvantage, even after the implementation of dental public health measures. This disease profile is reflected in the high prevalence of unmet oral health needs, often on account of the high cost of professionally delivered dental care and significant burden for payers at point-of-care delivery and for health systems (3, 5-7).

Health needs vary among countries and even within the same country; many of such variations are determined by demographic, social, cultural, economic and political conditions. Measuring health needs allows the evaluation of the impact of existing interventions, as well as monitoring epidemiologic trends $(8,9)$. While subjective self-reported health symptoms, diseases, injuries, and disabilities offer an expedient and inexpensive way of collecting information, an approach involving trained health personnel with clinical examinations $(9,10)$ is often preferred. Some authors have mentioned one more approach, which is gauging the utilization of health services - both formal and informal services assuming that an increase in utilization rates reflects increased health need (9). Studies on oral health treatment needs are especially sparse among adolescents (6) in Mexico. Most studies, focussed on Mexican adolescents, have used widely accepted but relatively coarse metrics such as the mean number of decayed, missing (due to caries), and filled teeth $[\mathrm{DMFT}](3,4,6)$. Although such epidemiological assessments add to the current state of knowledge, they fail to discern between teeth affected by the disease at different stages of severity or progression, and they also omit a dynamic measure of teeth affected as a proportion of the teeth already erupted and present in the mouth. The state of knowledge about burden of disease and its implications is incomplete; it is thus important to document morbidity levels, and to develop metrics to accurately estimate distinct morbidity manifestations in the context of treatment needs.

The aims of the present study were 1) to determine treatment needs for dental caries, and 2) to examine the face validity of a proposed index to gauge the prevalence of tooth extractions (signifying the likely outcome of late stages of the natural history of dental caries), among Mexican adolescents 12 to 15 years of age.

\section{SUBJECTS AND METHODS}

This study followed the ethical guidelines laid out for studies conducted at the Dental School, National University of Mexico and the Autonomous University of the State of Hidalgo.

This analysis is part of a larger project that measured diverse oral health indicators (Methods and results for dental caries (11), dental fluorosis $(10,12,13)$, tooth loss (14) and health services utilization (7) have been previously pub- 
lished). A cross-sectional survey targeted school children 12 and 15 years of age $(n=1768)$ from schools $(n=32)$ in three of the six locations of the Tula de Allende municipality located in the state of Hidalgo, Mexico. Seven schools (with 139 subjects) did not participate in the study due to logistic limitations; 91 adolescents were excluded for diverse reasons. A descriptive analysis on treatment needs was done. Only 1538 teenagers were included in the present report.

The dependent variables in this analysis were the Treatment Needs Index [TNI] (15) for dental caries, the Care Index [CI] (16) (targeting restorative care), and the Tooth Extractions Index (TEI). All of these were derived from the DMFT index, which measures present (component decayed teeth) and past (components missing and filled teeth) caries experience in permanent teeth. School children were clinically examined (with a dental probe and flat dental mirror under daylight) in their school for caries experience by two dental examiners trained in the criteria used in DMFT epidemiological surveys according to WHO (17).

The TNI calculates the relationship between untreated decayed teeth, and teeth treated with restorations or extractions [due to caries] (15):

$\mathrm{TNI}=\frac{\text { decayed teeth }}{\text { missing teeth }+ \text { filled teeth }}(100)$

The CI estimates the proportion of teeth that have received restorative care (16):

$\mathrm{CI}=\frac{\text { filled teeth }}{\text { DMF }}(100)$

This paper proposes the TEI, which represents the percentage of lost teeth due to dental caries compared to the teeth erupted and present:

$\mathrm{TEI}=\frac{\text { Tooth loss by caries }}{\text { teeth total evaluated }}(100)$.

Under TEI, teeth evaluated (denominator) include teeth with any condition (including missing teeth due to caries) except unerupted. Thus the index adjusts for teeth that have not yet erupted, a feature ignored by DMFT. In this fashion, the TEI is different between two teenagers who are both missing one tooth: if one has 15 teeth and the other 20 teeth, the missing tooth represents different percentages (one of 15 $=6.7 \%$ vs one of $20=5.0 \%$ ).

Using two questionnaires (one aimed at teenagers and another at their mothers/guardians), we established sociodemographic, socio-economic, and behavioural variables namely, gender, subject's age, current town of residence, and town of birth, if the mother could read and write, maximum level of formal schooling and occupation for parents, whether the teenager had health insurance (public or private) and an estimate of recent oral health services utilization (the teenager having at least one dental visit in preceding 12 months).

\section{Statistical analysis}

An indicator of socio-economic position (SEP) was constructed using occupation of both parents. These variables were combined using principal component analysis polychoric correlation (18). The first component explained $59.8 \%$ of the variability and was divided in tertiles, with the third tertile representing the highest SEP. Given that some mother and father information was missing, data were imputed using imputation by regression (19).

Statistical analysis consisted of determining the percentages and frequencies throughout the variable categories. Admittedly limited, this analytic approach was purposefully chosen because the use of composite indicators precluded a more detailed, individual-level analysis. They are population-level indicators; examples in oral epidemiology have been used beforehand, such as the Fluorosis Community Index (20) or the Significant Caries Index (21).

\section{RESULTS}

Descriptive data are in Table 1. A total of 1538 adolescents were incorporated in the study: 850 were 15 years old and

Table 1: Description of the characteristics of the study adolescents

\begin{tabular}{lcc}
\hline Variables & Frequency & Percentage \\
\hline Age $\quad$ & \\
$\quad$ 12 years & 688 & 44.7 \\
$\quad$ 15 years & 850 & 55.3 \\
Gender & & \\
$\quad$ Male & 770 & 50.1 \\
$\quad$ Female & 768 & 49.9 \\
Has always lived in same community? & 1095 & 71.2 \\
$\quad$ Yes & 443 & 28.8 \\
$\quad$ No & & \\
Had a visit to the dentist in the past 12 months? & 1306 & 85.0 \\
$\quad$ No & 231 & 15.0 \\
$\quad$ Yes & & \\
Mother can read and write? & 80 & 5.2 \\
$\quad$ No & 1458 & 94.8 \\
$\quad$ Yes & & \\
Teen has health insurance? & 526 & 34.2 \\
$\quad$ No & 796 & 51.8 \\
$\quad$ Public insurance & 216 & 14.0 \\
$\quad$ Private insurance & & \\
Mother's maximum level of schooling & 780 & 50.7 \\
$\quad$ 6 years & 758 & 49.3 \\
$\quad$ > years & & \\
Father's maximum level of schooling & 764 & 49.7 \\
$\quad$ 6 years & 774 & 50.3 \\
$\quad$ > y years & & \\
Socio-economic position & 538 & 35.0 \\
$\quad$ 1st tertile (lowest) & 521 & 33.9 \\
2nd tertile & & \\
$\quad$ 3d tertile (highest) & & \\
\hline
\end{tabular}

688 were 12 years old. The gender distribution was similar: $50.1 \%$ were male and $49.9 \%$, female. The location where more teenagers lived was Tula (51.4\%) and the lowest in El Llano, (11.4\%). According to the self-report, 28.8\% (n = 
443) did not always live in the same community. More than half $(51.8 \%)$ had health insurance coverage with either one of the two largest, employment-related third-party funded health plans in Mexico: IMSS (Mexican Institute of Social Security) or ISSSTE [Institute of Security and Social Services for State Workers] (both publicly funded, with plandefined contri-butions from employers and employees). Only $14.0 \%$ had some type of private health insurance. About one-third of the population had no health insurance.

Only $15.0 \%$ reported having had a dental visit in the year before the study. Most mothers (94.8\%) indicated they could read and write but half of the mothers $(50.7 \%)$ had only six years of schooling or fewer; about the same proportion pertained to fathers $(49.7 \%)$. In terms of family structure, it was found that only $5.6 \%$ of adolescents lived with one parent, either father or mother.

Teenagers had an average of 25.3 sound teeth: DMFT was 1.15 , with 0.82 decayed, 0.05 missing, and 0.28 filled teeth.

Table 2 shows the distribution of TNI, CI, and TEI. Treatment needs index was higher in 12-year olds, while 15-

Table 2: Distribution of treatment needs (TNI) for dental caries, care index (CI) and tooth extraction index (TEI) in Mexicans adolescents

\begin{tabular}{|c|c|c|c|}
\hline Variables & TNI & CI & TEI \\
\hline \multicolumn{4}{|l|}{ Age } \\
\hline 12 years & 78.8 & 20.0 & 0.16 \\
\hline 15 Years & 72.5 & 26.5 & 0.18 \\
\hline \multicolumn{4}{|l|}{ Gender } \\
\hline Male & 78.3 & 20.9 & 0.14 \\
\hline Female & 71.3 & 27.3 & 0.21 \\
\hline \multicolumn{4}{|c|}{ Has always lived in same community? } \\
\hline No & 75.2 & 23.9 & 0.16 \\
\hline Yes & 73.0 & 25.6 & 0.22 \\
\hline \multicolumn{4}{|c|}{ Had a visit to the dentist in the past 12 months? } \\
\hline No & 77.4 & 21.8 & 0.31 \\
\hline Yes & 63.7 & 34.0 & 0.15 \\
\hline \multicolumn{4}{|c|}{ Mother can read and write? } \\
\hline No & 97.2 & 2.5 & 0.45 \\
\hline Yes & 73.6 & 25.2 & 0.16 \\
\hline \multicolumn{4}{|c|}{ Teen has health insurance? } \\
\hline No & 78.0 & 21.0 & 0.19 \\
\hline Public insurance & 73.6 & 25.2 & 0.16 \\
\hline Private insurance & 73.8 & 25.2 & 0.18 \\
\hline \multicolumn{4}{|c|}{ Mother's maximum level of schooling } \\
\hline$\leq 6$ years & 80.4 & 18.8 & 0.17 \\
\hline$>6$ years & 69.3 & 29.4 & 0.18 \\
\hline \multicolumn{4}{|c|}{ Father's maximum level of schooling } \\
\hline$\leq 6$ years & 81.4 & 17.6 & 0.17 \\
\hline$>6$ years & 69.7 & 28.9 & 0.18 \\
\hline \multicolumn{4}{|l|}{ Socio-economic position } \\
\hline 1st tertile (lowest) & 78.4 & 20.8 & 0.18 \\
\hline 2nd tertile & 78.5 & 20.5 & 0.18 \\
\hline 3d tertile (highest) & 66.9 & 32.0 & 0.17 \\
\hline
\end{tabular}

year olds had higher CI and TEI. Boys had higher treatment needs and girls had both higher restorative treatment and extraction experience. Adolescents who had changed their place of residence in the area from the town they were born (internal migration) had more treatment needs for dental caries but had lower CI and TEI. Those teenagers who had at least one dental visit in the past year had lower treatment needs and higher restorative care index, while those who had no dental visit during the last year showed greater TEI.

With regard to socio-economic status, those teenagers whose families were in the highest tertile of the SEP (based on occupation), whose parents had attained education beyond elementary school, and whose mothers indicated they could read and write, had lower treatment need for dental caries (TNI) and greater experience of restorative care (CI). Although the experience of extractions (TEI) among teenagers was similar between the categories of schooling and occupational variables, the self-reported ability to read and write in the mother of the teenager was associated with a three-fold TEI difference. Teenagers who did not have health insurance coverage showed higher need for restorative treatment (TNI) and higher experience of tooth extractions (TEI), and had fewer restorations in their mouths (lower CI) compared to teenagers who had public or private health insurance.

\section{DISCUSSION}

From an epidemiological point of view, the study of health needs in general (and oral health in particular) across different population groups allows focussing of human and financial resources to solve health problems. As in other studies from different parts of the world [mainly developing countries (22-25)], we identified an uneven mosaic of treatment needs for dental caries; however, mean DMFT was relatively low, with the untreated decay component being the most important factor. Fewer than one tooth on average had a carious lesion considered advanced enough to be diagnosed as cavitated.

However, there were substantial unmet treatment needs, and also evidence that some carious lesions had progressed to a stage in which the tooth had to be extracted. In a perfect world, little or no disease would exist; in a slightly less perfect world, existing disease would be treated in a timely manner, therefore rendering the unmet treatment need and the signs of advanced progression of disease to a minimum. But in our real world, we must discuss the likely factors why people have dental caries lesions without treatment. One such factor is the concept that people have about oral diseases. If dental caries are not perceived as a real (or an important) health problem, individuals would not assume the "sick role" and contribute to high rates of untreated illness. The subjective perception of disease is a result of several biopsychosocial factors: "feeling sick" and "medically evaluated disease" are important components in the context of health. Despite clinical evidence of disease, the individual may not feel ill and thus adopt what has been called "medically defined disease without subjectively perceived disease" (26). Moreover, the subjective experience of illness is influenced by sociocultural factors; individuals are 
influenced by cultural norms of what to do when feeling pain or discomfort, how to express these feelings verbally and nonverbally, how and from whom to request assistance, and the expected roles and rules to behave as a sick person. Because of the low mortality and limited disability perceived to be caused by oral diseases, we may be witnessing a situation in which oral health problems are relegated to a secondary level of importance (26).

A separate yet possibly overlapping situation is present when disease occurs and it is perceived as a need by the individual. Seeking care is conditioned by factors that often are beyond the control of individuals such as barriers to adequate access $(7,9)$. Low coverage for oral health needs among adults in Mexico has been documented (27); because there are no special provisions for making clinical care easier to access in younger age groups, there is no evidence that the coverage problem may be any different for children and adolescents. Relatively few children and adolescents receive dental services $(5,7,28-30)$.

Our findings suggested that the profiles of met and unmet treatment needs fitted predictable patterns, as they resembled features in which higher social disadvantage were more likely to have association with poorer outcomes in caries treatment. The results for the proposed TEI pointed in the same direction, and thus lend limited validation because of its resemblance to the trends in the TNI and CI. One factor to meeting health needs is being in fact able to use care services when needed $(31,32)$. Social epidemiology has consistently studied health inequalities, that is, that people from better socio-economic position have better levels of health; but the exact mechanism underlying this link is not well understood (33). In the present study, it was found that people with better socio-economic position had fewer treatment needs for dental caries, lower experience of dental extractions, and a higher experience of receiving restorative care. While these trends held when contrasting various indicator variables - such as access to health insurance (public or private), higher level of formal schooling of the mother and father, and socio-economic position according to occupation - it was evident that one fundamental indicator was whether the mother could read and write. Because this is a single variable, with little apparent confusion or selfreport bias, it may be a high sensitivity question to discriminate between those who have and those who do not have better oral health profiles.

The present study has limitations that must be taken into account to correctly interpret the findings. First, its cross-sectional design may lead to inaccuracies in estimating cause and effect. Also, resorting to self-reported variables introduces possibly biased perspectives that study participants might have of their own situations. In terms of strengths, we have proposed an individual- and a populationlevel indicator of tooth extractions; this tool will allow comparisons between population groups, over time in the same group.
In conclusion, we can say that in this population of Mexican adolescents, we observed some unmet treatment need for dental caries (TNI) and little experience of restorative treatment $(\mathrm{CI})$. Although the experience of extractions (TEI) was limited, the fact that there were some extracted teeth at these early ages can serve as an indicator of poor oral health and restricted dental service utilization for future comparisons. While it is generally necessary to expand programmes aiming at the prevention of dental caries $(34,35)$, putting special attention on the physical, biological, cultural and access characteristics for different age groups appears necessary to effectively address unmet oral health needs of adolescents.

\section{REFERENCES}

1. Celis-de la Rosa A. La salud de adolescentes en cifras. Salud Publica Mex 2003; 45 (Suppl 1): S153-66.

2. Christie D, Viner R. Adolescent development. BMJ 2005; 330: 301-4.

3. Medina-Solis CE, Maupomé G, Pérez-Núñez R, Avila-Burgos L, Pelcastre-Villafuerte B, Pontigo-Loyola AP. Política de salud bucal en México: disminuir las principales enfermedades de salud bucal. Rev Biomédica 2006; 17: 269-86.

4. Martínez-Pérez KM, Monjarás-Ávila AJ, Patiño-Marín N, LoyolaRodríguez JP, Mandeville PB, Medina-Solís CE et al. Estudio epidemiológico sobre caries dental y necesidades de tratamiento en escolares de 6 a 12 años de edad de San Luis Potosí, México. Rev Invest Clín 2010; 62: 206-13.

5. Medina-Solís CE, Maupomé G, Avila-Burgos L, Hijar-Medina M, Segovia-Villanueva A, Pérez-Núñez R. Factors influencing the use of dental health services by preschool children in Mexico. Pediatr Dent 2006; 28: 285-92.

6. de la Fuente-Hernández J, González de Cossío M, Ortega-Maldonado M, Sifuentes-Valenzuela MC. Caries y pérdida dental en estudiantes preuniversitarios mexicanos. Salud Publica Mex 2008; 50: 235-40.

7. Pontigo-Loyola AP, Medina-Solís CE, Márquez-Corona ML, VallejosSánchez AA, Minaya-Sánchez M, Escoffié-Ramirez M et al. Influencia de variables predisponentes, facilitadoras y de necesidades sobre la utilización de servicios de salud bucal en adolescentes mexicanos en un medio semi-rural. Gac Med Mex 2012; 148: 218-26.

8. Liberatos P, Elinson J, Schaffzin T, Packer J, Jessop DJ. Developing a measure of unmet health care needs for a pediatric population. Med Care 2000; 38: 19-34.

9. Salinas-Martínez A, Muñoz-Moreno F, Barraza de León AR, VillarrealRíos E, Núñez-Rocha GM, Garza-Elizondo ME et al. Necesidades en salud del diabético usuario del primer nivel de atención. Salud Publica Mex 2001; 43: 324-35.

10. Medina-Solís CE, Pontigo-Loyola AP, Maupomé G, LamadridFigueroa H, Loyola-Rodríguez JP, Hernández-Romano J et al. Dental fluorosis prevalence and diagnostic test using Dean's index based on 6 teeth, and on 28 teeth. Clin Oral Investig 2008; 12: 197-202.

11. Pontigo-Loyola AP, Medina-Solis CE, Borges-Yáñez SA, Patiño-Marín N, Islas-Márquez AJ, Maupomé G. Prevalence and severity of dental caries in adolescents ages 12 and 15 living in communities with various fluoride concentrations. J Public Health Dent 2007; 67: 8-13.

12. Pontigo-Loyola AP, Islas-Márquez AJ, Loyola-Rodríguez JP, Maupomé G, Márquez-Corona ML, Medina-Solís CE. Dental fluorosis in 12- and 15 -year-olds at high altitude in above optimal fluoridated communities in Mexico. J Public Health Dent 2008; 68: 163-6.

13. Pontigo-Loyola AP, Medina-Solís CE, Lara-Carrillo E, Patiño-Marín N, Escoffié-Ramírez M, Mendoza-Rodríguez $\mathrm{M}$ et al. Impact of sociodemographic, socio-economic, and water variables on dental fluorosis in adolescents growing up during the implementation of a fluoridated domestic salt program. Odontology 2014; 102: 105-15. Epub 2012 Dec 8

14. Pontigo-Loyola AP, Medina-Solís CE, Veras-Hernández M, Vallejos- 
Sánchez AA, Minaya-Sánchez M, Mendoza-Rodríguez $\mathrm{M}$ et al. Prevalencia de dientes perdidos y factores asociados en una muestra de adolescentes hidalguenses. Boletin Informativo de la Coordinación de Investigación 2011; 43: 6-9.

15. Jong A. Dental public health community dentistry. St Louis: Mosby Co; 1981; 74-88.

16. Walsh J. International patterns of oral health care - the example of New Zaeland. NZ Dental J 1970; 66: 143-52.

17. WHO. Oral Health Survey - Basics Methods. $4^{\text {th }}$ ed. Geneva: World Health Organization; 1997.

18. Kolenikov S, Angeles G. The use of discrete data in principal component analysis: theory simulations and applications to socio-economic indices [CD-ROM]. Working paper No. WP-04-85. North Carolina: CPC/MEASURE; 2004.

19. McKnight PE, McKnight KM, Sidani S, Figueredo AJ. Missing data: a gentle introduction. New York: Guilford; 2007.

20. Jayaprakash K. Dental indices. In: Jayaprakash K. A short textbook of preventive and community dentistry. New Delhi: Jaypee Brothers Medical Publisher Ltd; 2004: 58-74.

21. Bratthall D. Introducing the Significant Caries Index together with a proposal for a new global oral health goal for 12-year-olds. Int Dent J 2000; 50: 378-84

22. Thippeswamy HM, Kumar N, Acharya S, Pentapati KC. Relationship between body mass index and dental caries among adolescent children in South India. West Indian Med J 2011; 60: 581-6.

23. van Wyk C, van Wyk PJ. Trends in dental caries prevalence, severity and unmet treatment need levels in South Africa between 1983 and 2002. SADJ 2010; 65: 312-4.

24. Huew R, Waterhouse PJ, Moynihan PJ, Maguire A. Prevalence and severity of dental caries in Libyan school children. Int Dent J 2011; 61: 217-23.

25. Molina-Frechero N, Pierdant-Rodríguez AI, Oropeza-Oropeza A, Bologna-Molina R. Fluorosis and dental caries: an assessment of risk factors in Mexican children. Rev Invest Clin 2012; 64: 67-73.

26. Di Silvestre C. Somatización y percepción subjetiva de la enfermedad. Cinta de Moebio 1998; [cited 2012 Mar 10]. Available from: http://www.redalyc.org/articulo.oa?id=10100407
27. Pérez-Núñez R, Medina-Solis CE, Maupomé G, Vargas-Palacios A. Factors associated with dental health care coverage in Mexico: findings from the National Performance Evaluation Survey 2002-2003. Community Dent Oral Epidemiol 2006; 34: 387-97.

28. Medina-Solís CE, Villalobos-Rodelo JJ, Márquez-Corona ML, Vallejos-Sánchez AA, López Portillo-Núñez C, Casanova-Rosado AJ. Desigualdades socioeconómicas en la utilización de servicios de salud bucal: estudio en escolares mexicanos de 6 a 12 años de edad. Cad Saude Publica 2009; 25: 2621-31.

29. Villalobos-Rodelo JJ, Medina-Solís CE, Maupomé G, LamadridFigueroa H, Casanova-Rosado AJ, Casanova-Rosado JF et al. Dental needs and socio-economic status associated with utilization of dental services in the presence of dental pain: a case control study in children. J Orofac Pain 2010; 24: 279-86.

30. Medina-Solis CE, Maupomé G, Herrera MS, Avila-Burgos L, PérezNúñez R, Lamadrid-Figueroa H. Dental health services utilization in children 6-12 years old in a low-income country. J Public Health Dent 2008; 68: 39-45.

31. Khare V, Koshy A, Rani P, Srilatha S, Kapse SC, Agrawal A. Prevalence of dental caries and treatment needs among the orphan children and adolescents of Udaipur district, Rajasthan, India. J Contemp Dent Pract 2012; 13: 182-7.

32. García-Peña C, González-González C. Accesibilidad y efectividad en México. Gac Med Mex 2011; 147: 504-9.

33. Kawachi I. Income inequality in health. In: Berkman L, Kawachi I. Social Epidemiology. New York: Oxford University Press; 2000: 76-93.

34. Casanova-Rosado JF, Vallejos-Sánchez AA, Minaya-Sánchez M, Medina-Solís CE, De La Rosa-Santillana R, Márquez-Corona ML et al. Frequency of tooth brushing and associated factors in Mexican school children six to nine years of age. West Indian Med J 2013; 62: 68-72.

35. Ramroop V, Wright D, Naidu R. Dental health knowledge and attitudes of primary school teachers toward developing dental health education. West Indian Med J 2011; 60: 576-80. 